\title{
Antibacterial and Antifungal Activity Analysis of Essential Oil of Pogostemon cablin (Blanco) Benth
}

\author{
Puspa Das ${ }^{1}$, Shoma Dutta ${ }^{1}$, Jaripa Begum², Md. Nural Anwar ${ }^{1}$ \\ ${ }^{1}$ Department of Microbiology, University of Chittagong, Chittagong-4331, Bangladesh, ${ }^{2}$ Bangladesh Council of Scientific \& Industrial Research \\ (BCSIR) Laboratories, Chittagong; Bangladesh
}

\begin{abstract}
The essential oil of Pogostemon cablin (Blanco) Benth, also known as Patchouli oil was subjected for its antimicrobial investigation against a panel of ten human pathogenic bacteria and six human pathogenic fungi by Agar well diffusion method and Macrobroth dilution technique using Ampicillin (20ig/well) and Nystatin (20 $\mathrm{g} / \mathrm{well})$ as control. Antibacterial activity revealed that, the essential oil was more active against Gram positive bacteria than Gram negative bacteria. The largest zone of inhibition was 35 mm (against Bacillus cereus) with $20 \mu \mathrm{l}$ of oil. Ditermination of Minimum Inhibitory Concentration (MIC) and Minimum Bactericidal Concentration (MBC) showed that, Bacillus cereus exhibited the lowest MIC (250 $\mu \mathrm{g} / \mathrm{ml})$ and MBC $(750 \mu \mathrm{g} / \mathrm{ml})$. The oil showed moderate antifungal activity against all tested organisms. Candida albicans showed greater zone of inhibition $(16 \mathrm{~mm})$ than Saccharomyces cerevisiae $(14 \mathrm{~mm})$ with $20 \mu \mathrm{l}$ and Candida albicans showed lowest MIC and MFC (both were $750 \mu \mathrm{g} / \mathrm{ml}$ ). The zone of inhibition was $25 \mathrm{~mm}$ for each filamentous fungal strain with $20 \mu \mathrm{l}$, except for Rhizopus oligosporus $(15 \mathrm{~mm})$ and the lowest MIC (250 $\mathrm{gg} / \mathrm{ml})$ and MFC $(500 \mu \mathrm{g} / \mathrm{ml})$ were reported for Aspergillus fumigatus.
\end{abstract}

Keywords: Pogostemon cablin (Blanco) Benth, Patchouli oil, Antimicrobial activity

\section{Introduction}

Over the past years, the problem of antimicrobial resistance has received increasing attention and has become a global concern ${ }^{1}$. In addition, the increased magnitude of emergence of bacterial drug resistance, high dosage and prolonged antimicrobial therapy could eliminate commensal and beneficial bacteria and be predisposing to pathogen invasion ${ }^{2,3}$. Moreover, food-borne disease is still a major problem in the world, even in well-developed countries ${ }^{4}$. Nowadays, there is a growing interest in the screening of extracts and essential oils from plants in order to discover new antimicrobial agents. Pogostemon cablin (Blanco) Benth, also known as "Patchouli" or "Putchaput" is a species belonging to the family of Lamiaceae from the genus Pogostemon. The plant is native to tropical regions of Asia and is now extensively cultivated in China, Indonesia, India, Malaysia, Mauritius, Philippines, Thailand, Vietnam, and West Africa. It was introduced in India in 1942 and various cultivars were being evaluated for its suitability to tropical humid South Indian conditions ${ }^{5}$. The main constituents in essential oil are patchouli alcohol (49.06ÿ), á-bulnesene (14.34 $\%), \alpha$-patch-oulene (5.24\%), $\beta$-Carophyllene (3.90\%), $\beta$ patchoulene (3.11\%), Globulol (1.41\%), Caryophyllene oxide (1.08\%), spathulenol (0.79\%) etc ${ }^{6}$. History says that, Patchouli oil is very effective in sorting out rough, cracked and overly dehydrated skin and is used to treat acne, eczema, sores, ulcers, fungal infections, as well as scalp disorders. Chinese medicine uses the herb to treat headache, cold, nausea, diarrhea and abdominal pain ${ }^{7}$. Previous data showed that, crude hexane extraction patchouli leaves shows strong antibacterial activity against Gram positive bacteria e.g. Staphylococcus aureus and Bacillus subtilis $^{8-9}$. There is no substantial data on patchouli oil. The aim of the present work was to investigate antimicrobial activities of patchouli oil against a diverse range of human pathogenic organisms including Gram positive and Gram negative bacteria and fungi in order to look for natural antimicrobial agents.

\section{Materials and Methods \\ Collection of the essential oil}

The patchouli oil was collected from BCSIR Laboratories, Chittagong which formerly cultivated, harvested and extracted essential oil by hydrodistillation. Chemical composition was analyzed and identified by GC-MS electron impact ionization (EI) method on GC-17A gas chromatography (Shimadzu, Japan) under BCSIR Laboratories, Chittagong 6 .

\section{Test organisms}

The patchouli oil was tested for its antimicrobial activities against ten human pathogenic bacteria, two human pathogenic yeasts and four human pathogenic molds. Among ten human pathogenic bacteria, three were Gram positive, viz, Bacillus subtilis BTCC17, Bacillus cereus BTCC19, Staphylococcus aureus ATCC6538 and seven were Gram negative bacteria, viz., Salmonella Typhi

*Corresponding author:

Dr. Md. Nural Anwar, Professor,Department of Microbiology; University of Chittagong, Chittagong, Bangladesh

Tel(Office)031-726311-14,Ext-4464: Cell-01716430243,Email:anwarmn51@yahoo.com 
AE14296, Salmonella Paratyphi AE14298, Pseudomonas aeruginosa ICDDR,B, Shigella sonnei ICDDR'B, Shigella dysenteriae AE14612, Vibrio cholerae AE14748, and Escherichia coli ATCC25922.The two human pathogenic yeasts were Candida albicans ATCC10231 and Saccharomyces cerevisiae (Proff. Scarsman, Australia) and the four human pathogenic molds were Rhizopus oligosporus ATCC22959, Aspergillus flavus ATCC9807, Aspergillus fumigatus ATCC16903, Fusarium equisetti ATCC15622. Bacterial test organisms were collected from the Department of Microbiology, University of Chittagong. Fungal cultures were collected from BCSIR Laboratories, Dhaka.

\section{Determination of antibacterial and antifungal activity}

In vitro sensitivity of the bacterial and fungal strains to the test materials was carried out by using Agar well diffusion method using growth media, e.g. Muller Hington Agar (MHA) for bacteria, Sabouroud Dextrose Agar (SDA) for yeast and Potato Dextrose Agar (PDA) for mold ${ }^{10}$. In order to perform the antimicrobial screening, colonies collected from each twenty-four hours bacterial culture were diluted in sterile saline and the optical density was adjusted according to the tube 0.5 of McFarland scale to prepare a standardized inoculum $\left(1.5 \times 10^{8} \mathrm{cfu} / \mathrm{ml}\right)^{11}$. Forty-eight hours old culture of yeast from SDA media were used for preparing a standardized inoculum $\left(1.5 \times 10^{6} \mathrm{cfu} / \mathrm{ml}\right)$ and spore suspension containing $1.5 \times 10^{8} \mathrm{cfu} / \mathrm{ml}$ of five days old culture of mold from PDA media were used. Fixed volumes (20 $\mu \mathrm{l}$ and $10 \mu \mathrm{l})$ of the essential oil of the plant was used. The control was $0.1 \mathrm{ml}$ of soybean oil. After plating and inoculation the plates were kept at low temperature $\left(4^{\circ} \mathrm{C}\right)$ for $2-4 \mathrm{hrs}$ to allow maximum diffusion of the material. The diffusion occurs according to the physical law that controls the diffusion of molecules through agar gel ${ }^{12}$. The agar cup-plates were incubated in an upright position and readings were then taken. The results were obtained by measuring the diameters of the zones of complete inhibition after $24 \mathrm{hrs}$ at $37^{\circ} \mathrm{C}$ for bacteria, $48 \mathrm{hrs}$ at $37 \pm 1^{\circ} \mathrm{C}$ for yeast and 5 days $27 \pm 2^{\circ} \mathrm{C}$ for molds. Bacterial results were compared with standard bacterial

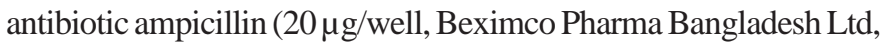
Dhaka) and fungal results were compared with standard fungal antibiotic Nystatin (20 $\mu \mathrm{g} /$ well, Beximco Pharma Bangladesh Ltd, Dhaka).

\section{Determination of MIC, MBC and MFC}

MIC, MBC and MFC of the essential oil of Pogostemon cablin against all the above test organisms were performed against all the teste organisms by using Macrobroth dilution technique ${ }^{13}$. Peptone broth (2\%) for bacteria, Sabouroud Broth for yeast and Potato Dextrose Broth (PDB) for mold were used in MIC test. DMSO (Dimethyl sufoxide) was used to dissolve the essential oil and then diluted to the highest concentration ranging from 125 to $3000 \mathrm{ig} / \mathrm{ml}$ in the case of bacteria and from 250 to $4000 \mu \mathrm{g} / \mathrm{ml}$ in the case of yeast. One $\mathrm{ml}$ of suspension (for bacteria containing approx. $1.5 \times 10^{6} \mathrm{CFU} / \mathrm{ml}$ and for yeast containing approx. 1 x $10^{4}$ $\mathrm{CFU} / \mathrm{ml}$ ) of test organism was used as inoculum and control. After incubation at $37^{\circ} \mathrm{C}$ for $24-48$ hours for bacteria and at $25^{\circ} \mathrm{C}$ for 48 hours for yeast MIC results were recorded. For MBC testing Nutrient Agar (NA) medium for bacteria and SDA media for yeast were used. After incubation at $37^{\circ} \mathrm{C}$ for 48 hours for bacteria and at $25^{\circ} \mathrm{C}$ for 48 hours for yeast the lowest concentration that shows no colony or growth was determined as MBC. For MFC test, PDA used as basal medium and incubated at $27^{\circ} \mathrm{C}$ for 5 days.

\section{Results and Discussion}

Patchouli oil obtained from P. cablin was screened for its in vitro antibacterial activity against ten human pathogenic bacteria comparing to standard antibacterial antibiotic Ampicillin. The results of the sensitivity test are summarized in Table 1 . It was observed that the essential oil was more effective against all the test organisms when compared with Ampicillin. The zones of inhibition varied from a highest of $35 \mathrm{~mm}$ to a lowest of $20 \mathrm{~mm}$ using $20 \mu \mathrm{l}$ and from a highest of $23 \mathrm{~mm}$ to lowest of $12 \mathrm{~mm}$ using $10 \mu$ l. The biger zone of inhibition was recorded against Bacillus cereus ( $35 \mathrm{~mm}$ ) followed by Shigella sonnei $(33 \mathrm{~mm}$ ) whereas in case of Ampicillin (20 $\mu \mathrm{g} /$ well) the zone size were $25 \mathrm{~mm}$ for Bacillus cereus. The lowest zones of inhibition were found against

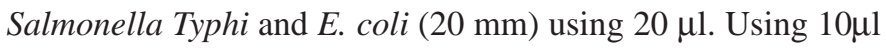
concentration the highest zone was found against Shigella sonnei (23 mm) followed by S. aureus (20 mm) and S. Paratyphi (20 mm).

Table 1. Antibacterial activity of essential oil of Pogostemon cablin

\begin{tabular}{|c|c|c|c|}
\hline \multirow[t]{3}{*}{ Test Bacteria } & \multicolumn{3}{|c|}{ Zones of inhibition ( $\mathrm{mm}$ in diameter) } \\
\hline & \multicolumn{2}{|c|}{ Dose ( $\mu \mathrm{l} /$ well) of essential oil } & \multirow[b]{2}{*}{$\begin{array}{l}\text { Ampicillin } \\
\text { (20 } \mu \mathrm{g} / \text { well) }\end{array}$} \\
\hline & 10 & 20 & \\
\hline Bacillus subtilis & 15 & 30 & 22 \\
\hline Bacillus cereus & 20 & 35 & 25 \\
\hline Staphylococcus aureus & 20 & 25 & 20 \\
\hline Salmonella typhi & 15 & 20 & 25 \\
\hline Salmonella paratyphi & 20 & 30 & 30 \\
\hline Pseudomonas aeruginosa & 17 & 25 & 19 \\
\hline Shigella sonnei & 23 & 33 & 20 \\
\hline Shigella dysenteriae & 12 & 24 & 25 \\
\hline Vibrio cholerae & 22 & 30 & 24 \\
\hline Escherichia coli & 16 & 20 & 15 \\
\hline
\end{tabular}

The MIC values of the essential oil varied against different test bacteria ranging from $250 \mu \mathrm{g} / \mathrm{ml}$ to $1000 \mu \mathrm{g} / \mathrm{ml}$ (Table 2). The results showed that Bacillus cereus and Salmonella Paratyphi exhibited the lowest MIC ( $250 \mu \mathrm{g} / \mathrm{ml})$. Their MBC $(750 \mu \mathrm{g} / \mathrm{ml})$ was higher than MIC which means that this oil is bacteriostatic for these bacteria. MIC against B. subtilis, S. dysenteriae and Pseudomonas aureginosa were found to be $(500 \mu \mathrm{g} / \mathrm{ml})$ and MBC the highest resistance at $750 \mu \mathrm{g} / \mathrm{ml}, 1000 \mu \mathrm{g} / \mathrm{ml}$ and $500 \mu \mathrm{g} / \mathrm{ml}$ respectively. Salmonella typhi showed resistance against this oil, because the MIC was $4500 \mu \mathrm{g} / \mathrm{ml}$ for this bacterium, which was higher than others. No MBC was found for this bacterium within the range of $4500 \mu \mathrm{g} / \mathrm{ml}$. 
Table 2 MIC (Minimum Inhibitory Concentration) and MBC (Minimum Bacteriocidal Concentration) of essential oil (EO's) of Pogostemon cablin against test bacteria

\begin{tabular}{lcc}
\hline Test bacteria & $\begin{array}{c}\text { Dose (concentration of EO’s in } \mu \mathrm{g} / \mathrm{ml}) \\
\text { MIC }(\mu \mathrm{g} / \mathrm{ml})\end{array}$ & MBC $(\mu \mathrm{g} / \mathrm{ml})$ \\
\hline Bacillus subtilis & 500 & 750 \\
Bacillus cereus & 250 & 750 \\
Staphylococcus aureus & 1000 & 1250 \\
Salmonella Typhi & $-*$ & $-*$ \\
Salmonella Paratyphi & 250 & 750 \\
Pseudomonas aeruginosa & 500 & 500 \\
Shigella sonnei & 750 & 750 \\
Shigella dysenteriae & 500 & 1000 \\
Vibrio cholerae & 750 & 750 \\
Escherichia coli & 500 & 750 \\
\hline
\end{tabular}

* - Not detected

In the present study it was found that both gram-positive and gram-negative bacteria (except $S$. typhi) were susceptible to the oil. It can be noted that, an important characteristic of essential oil and their components is their hydrophobicity, which enables them to partition in the lipids of the bacterial cell membrane, distursbing the structures and rendering them more permeable ${ }^{14}$. Leakage of ions and other cell contents can then occur. Bacillus cereus was the most susceptible bacterium. This may attributed to the presence of single membrane of the organism that makes it more accessible to permeation by active constituents of this oil. In contrast, Salmonella typhi and E. coli showed least susceptibility (lowest zone of inhibition) to this oil. This may be due to the presence of outer membrane that serves as an effective barrier in gram-negative species ${ }^{15-16}$. Previous studies revealed that many terpenes, terpenoid, sesquiterpenoids show strong antibacterial activity. Patchouli alcohol is a terpene, $\alpha$ - patchoulene is a terpenoid and $\alpha$-bulnesene is a sesquiterpenoid that could be considered as answerable for the antimicrobial activity. In a brief, we can say that, the oil has showed strong bacteriocidal effect except $S$. typhi.

The results of in vitro antifungal activity of patchouli oil against six human pathogenic fungi by agar cup method with 10 and $20 \mu \mathrm{l}$ are presented in Table 3. The oil exhibited strong antifungal activity against all the tested fungi, but inhibition of the mycellial growth were more remarkable against four human pathogenic molds than the pathogenic yeasts. Candida albicans (16 mm) showed greater sensitivity against this oil than $S$. cerevisiae (14 $\mathrm{mm}$ ) with $20 \mu \mathrm{l}$. At $10 \mu \mathrm{l}$ Candida albicans showed $8 \mathrm{~mm}$ of zone of inhibition, where Saccharomyces cerevisiae showed $7 \mathrm{~mm}$ zone of inhibition. On the case of mold, almost all strains showed sensitivity against this oil. In most cases, the oil exhibited better antifungal activity than the standard antibiotic nystatin. In case of nystatin the highest zone was $25 \mathrm{~mm}$ for $A$. flavus. For oil it was $25 \mathrm{~mm}$ for each fungal strain with $20 \mu \mathrm{l}$ except for Rhizopus oligosporus $(15 \mathrm{~mm})$. At $10 \mu \mathrm{l}$ F. equisetti showed highest zone of inhibition (12 mm) followed by A. flavus (11 mm).
Table 3 Antifungal activity of essential oil of Pogostemon cablin

\begin{tabular}{|c|c|c|c|}
\hline \multirow[t]{3}{*}{ Test organisms } & \multicolumn{3}{|c|}{ Zones of inhibition ( $\mathrm{mm}$ in diameter) } \\
\hline & \multicolumn{2}{|c|}{ Dose ( $\mu \mathrm{l} /$ well) of essential o } & \multirow[b]{2}{*}{ 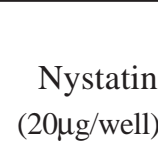 } \\
\hline & 10 & 20 & \\
\hline Candida albicans & 8 & 15 & 15 \\
\hline Saccharomyces cerevi & isiae 7 & 15 & 12 \\
\hline Rhizopus oligosporus & 7 & 16 & 20 \\
\hline Aspergillus flavus & 11 & 25 & 25 \\
\hline Aspergillus fumigatus & 10 & 25 & 23 \\
\hline Fusarium equisetti & 12 & 25 & 21 \\
\hline
\end{tabular}

The MIC values against different test fungi are presented in Table 4. In case of yeasts, Candida albicans showed lower MIC and MFC (both were $750 \mu \mathrm{g} / \mathrm{ml}$ ) than Saccharomyces cerevisiae, which were $1500 \mu \mathrm{g} / \mathrm{ml}$ and $2500 \mu \mathrm{g} / \mathrm{ml}$, respectively. In case of molds, the lowest MIC (250 $\mu \mathrm{g} / \mathrm{ml})$ and MFC (500 $\mu \mathrm{g} / \mathrm{ml})$ were reported for A. fumigatus. Though Rhizopus oligosporus showed lowest zone of inhibition (16mm), its MIC was $500 \mu \mathrm{g} / \mathrm{ml}$, which was lower than A. fumigatus and Fusarium sp., but it showed MFC $3000 \mu \mathrm{g} / \mathrm{ml}$ which was same as A. flavus. This means that this oil inhibits the growth of Rhizopus oligosporus at low concentration, but does not kill this fungus. For killing it require higher dose as same as A. flavus. The low MIC of the essential oil against fungal strains indicates that the main compounds present in the oil, patchouli alcohol, a terpene hydrocarbons had a stronger antifungal activity. In addition, $\alpha$-caryophyllene and caryophyllene oxide, detected in our experiments, could be responsible for this property ${ }^{17}$. In brief we can say that the oil has moderate fungicidal effect that may provide a renewable source for useful as bacteriocidal and fungicidal drugs.

Table 4 MIC (Minimum Inhibitory Concentration) and MFC (Minimum Fungicidal Concentration) of essential oils (EO's) of Pogostemon cablin against test fungi

\begin{tabular}{lcc}
\hline & \multicolumn{2}{c}{ Dose (concentration of EO’s at $\mu \mathrm{g} / \mathrm{ml})$} \\
\cline { 2 - 3 } \multicolumn{1}{c}{ Test organisms } & MIC $(\mu \mathrm{g} / \mathrm{ml})$ & MFC $(\mu \mathrm{g} / \mathrm{ml})$ \\
\hline Candida albicans & 750 & 750 \\
Saccharomyces cerevisiae & 1500 & 2500 \\
Rhizopus oligosporus & 500 & 3000 \\
Aspergillus flavus & 2000 & 3000 \\
Aspergillus fumigatus & 250 & 500 \\
Fusarium equisetti & 1500 & 1500 \\
\hline
\end{tabular}

\section{Conclusion}

The essential oil of $P$. cablin is a natural product that can be used against antibiotic resistance organisms and also could be used in food preservation. It may provide tomorrow's antibiotic source for useful bactericidal and fungicidal drugs that can be utilized against many food borne pathogens, in many opportunistic infection e.g. against Candida spp. in oral candidiasis as well as against $A$. fumigatus and $A$. flavus infection in patients suffering from pulmonary tuberculosis. It would be a valuable source to find out leading compounds having antimicrobial activity. 


\section{References}

1. Westh H, Zinn CS and Rosdahl VT. 2004. An international multicenter study of antimicrobial consumption and resistance in Staphylococcus aureus isolates from fifteen hospitals in forty countries. Micro Drug Resis. 10:169-176.

2. Carson CF and Riley TV. 2003. Non-antibiotic therapies for infectious diseases. Communicable Dis Intellig. 27: 143-146.

3. Guarner F and Malagelada JR. 2003. Gut flora in health and disease. Lancet. 361: 512-519.

4. Mead PS, Slutsker L, Dietz V, McCaig LF, Breese JS, Shapiro C, Griffin PM and Tauxe RV. 1995. Food related illness and dead in the United States. Emerg Infec Dis. 5: 607-625.

5. Kumar A, Gauniyal AK and Virmani OP. Cultivation of Pogostemon patchouli for its oil. 1986. Ind Perf. 8(2):79-86.

6. Rahman M, Shoeb M, Nandi NC, Alamgir M and Hussain M. 2001. Introduction of patchouli, Pogostemon cablin (Blanco) Benth; An essential oil bearing plant in Bangladesh. Bangl J Ind Sci Res. 36(14):14-18.

7. Esotoric oil, the world of pure essential oils, Pretoria South Africa. http://www.essentialoils.co.za/essential-oils/patchouli.

8. Ngampong K, Pornpat S, Boonsong K, Yupa P, Maliwan T and Pareeya U. 2009. Development of Patchouli extraction with quality control and isolation of active compounds with antibacterial activity. Kasetsart J (Nat Sci) 43: 519 - 525.

9. Senthilkumar CS, Suresh MK and Rajasekara MP. 2010. In vitro Antibacterial activity of crude leaf extracts from Tecoma stans ( $L$ )
Juss, Et. kuntha, Coleus forskohlii and Pogostemon patchouli against human pathogenic bacteria. Intern $J$ of PharmTech Res. 2(1): 438-442.

10. Rose SB and Miller RE. 1939. Studies with the Agar cup-plate method, Part- I: A standardized agar cup-plate technique. J Bact. 38: 525-537.

11. MacFaddin JF. 2000. Biochemical Tests for Identification of Medical Bacteria. $3^{\text {rd }}$ edn, Williams and Wilkins, Lippincott, New York.

12. Barry AL. 1976. Procedure for testing antimicrobial agents in agar media. In: Antibiotics in laboratory medicines (Lorian V ed.), pp 1123.Williams and Wilkins Co, Baltimore, USA.

13. NCCLS - 2003.National Committee for Clinical Laboratory Standards. Performance standards for antimicrobial susceptibility testing: eleventh informational supplement. Document M100-S11. National Committee for Clinical Laboratory Standard, Wayne, PA, USA.

14. Knobloch K, Weigand H, Weis N, Schwarm HM and Vigenschow H. 1986. Action of terpenoids on energy metabolism. In: Progress in Essential Oil Research (Brunke EJ, editor). pp 429-445.16th International Symposium on Essential Oils. De Gruyter, Berlin.

15. Nikaido H. 1999. Microdermatology: Cell surface, in the interaction of microbes with the external world. J Bact. 181: 4-8.

16. Adesokan A, Akanji MA and Yakubu MT. 2007. Antibacterial potentials of aqueous extract of Enantia chlorantha stem bark. African J Biotech. 6(22): 2502-2505

17. Charles DJ and Simon JE. 1990. Comparison of extraction methods for the rapid determination of essential oil content and composition of basil. J Am Hort Sci. 115: 458-462. 